\title{
PELATIHAN TARI KREASI SEBAGAI PENINGKATAN KOMPETENSI GURU MI/PAUD/RA RADEN FATAH
}

\author{
Emy Yunita Rahma Pratiwi ${ }^{1}$, Ratih Asmarani ${ }^{2}$, Evita Widiyati ${ }^{3}$ \\ Muhammad Nuruddin ${ }^{4}$, Claudya Zahrani Susilo ${ }^{5}$ \\ 1,2,4,5 Pendidikan Guru Sekolah Dasar, Universitas Hasyim Asy'ari Jombang \\ ${ }^{3)}$ Pendidikan Guru Madrasah Ibtidaiyah, Universitas Hasyim Asy'ari Jombang \\ 1emyyunita88@gmail.com
}

\begin{abstract}
This community service is one of the education services to the community, which is one of the programs in the field of KKNT of UNHASY Tebuireng Jombang students in Kedungbogo Village, Ngusikan District, Jombang Regency. One of those is conducting a dance training at Raden Fatah. The results of the study were: there is a lack of understanding of the concept and the importance of cultural arts education in classroom learning in terms of students' character development into humanistic characters through creativity, sense, and intention. The method used in implementing this community service is as follows: a) partner Situation Analysis, b) literature study, c) preparation of material to be presented as a problem solution, d) testing the results, e) revision products, f) the training implementation, and g) Regular mentoring.Based on those problems, it can be concluded that a) there must be an improvement in skills and competence of teachers related to the teaching and learning process in the schools environments, b) this training (community service) is expected to make teachers understand the concept and the importance of cultural arts education c) there must be a development of students' character to become humanistic character through creativity, taste, and initiative, displaying an attitude of appreciation for cultural arts, displaying creativity through cultural arts, and increase the participation of cultural arts events at the local, regional and global levels.
\end{abstract}

Keywords: Dance, Competency, Professional, Teacher, Raden Fatah

\begin{abstract}
Abstrak: Pengabdian ini merupakan salah satu pengabdian perguruan tinggi kepada masyarakat, yaitu salah satu program di bidang pendidikan KKNT mahasiswa UNHASY Tebuireng Jombang di Desa Kedungbogo Kecamatan Ngusikan Kabupaten Jombang, diantaranya melaksanakan Pelatihan Tari di Raden Fatah. Hasil analisis yang ditemukan adalah: Kurang adanya pemahaman konsep dan pentingnya pendidikan seni budaya pada pembelajaran di kelas sehingga kurang dalam hal pengembangan karakter peserta didik menjadi manusia yang humanistis melalui olah cipta, rasa, dan karsa. Metode pelaksanaan PKM adalah sebagai berikut: a) Analisis Situasi Mitra, b) Pengkajian pustaka c) Penyusunan materi sebagai solusi masalah, d) Uji coba, e) Revisi produk, f) Pelaksanaan pelatihan, dan g) Pendampingan berkala. Berdasarkan permasalahan tersebut maka dapat disimpulkan bahwa perlu adanya a) peningkatan keterampilan maupun kompetensi guru yang berkaitan dengan proses belajar mengajar di lingkungan Sekolah Dasar/Madrasah Ibtidaiyah maupun PAUD/RA perlu ditingkatkan. b) adanya pelatihan dalam PKM ini diharapkan menjadikan guru memahami konsep dan pentingnya pendidikan seni budaya c) mengembangkan karakter peserta didik menjadi manusia yang humanistis melalui olah cipta, rasa, dan karsa, menampilkan sikap apresiasi terhadap seni budaya, menampilkan kreativitas melalui seni budaya, dan meningkatkan peran serta seni budaya pada tingkat lokal, regional dan global.
\end{abstract}

Kata Kunci: Tari, Kompetensi, Professional, Guru, Raden Fatah

\section{Pendahuluan}

Kuliah Kerja Nyata Tematik (KKNT) dirancang sebagai salah satu pengabdian perguruan tinggi kepada masyarakat lewat penyuluhan, pembimbingan, pendampingan, dan lain-lain untuk membantu meningkatkan kualitas hidup berbagai lapisan masyarakat. Mahasiswa dibimbing oleh DPL untuk membuat 
Program kerja kelompok yang mana dibagi menjadi perdivisi antara lain keagamaan, pendidikan, kewirausahaan, kelembagaan, dan kesehatan. Setiap kelompok divisi menyusun program utama, pendukung, dan bantu untuk dijalankan serta diterapkan di masyarakat. Salah satu program di bidang pendidikan KKNT mahasiswa UNHASY Tebuireng Jombang di Desa Kedungbogo Kecamatan Ngusikan Kabupaten Jombang, diantaranya melaksanakan Pelatihan Tari yang diajarkan kepada siswi-siswi SD dan MI.

Secara jelas Desa Kedungbogo didominasi oleh daerah persawahan. Desa Kedungbogo memiliki 1 masjid yaitu Masjid Masykurullah, 1 Balai Desa, 2 Gedung TK, 1 Gedung SD, 1 Gedung MI, RA dan 1 Gedung SMP. Lokasi tersebut dengan mudah ditempuh dengan kendaran. Desa Kedungbogo memiliki luas 143.828 Ha.

Program Desa diawali dari musyawarah Dusun yang dilanjutkan ke musyawarah Desa yang dihadiri oleh tokoh-tokoh masyarakat, tokoh Agama, RT/RW, Pemerintah Desa beserta BPD dalam rangka penggalian gagasan. Dari penggalian gagasan tersebut dapat diketahui permasalahan yang ada di Desa dan kebutuhan apa yang diperlukan oleh masyarakat sehingga aspirasi seluruh lapisan masyarakat dapat tertampung.

Hasil observasi yang dilakukan di lokasi KKNT, Desa Kedungbogo merupakan desa yang sudah termasuk maju meskipun terletak di pinggir kota. Sebagian besar dari penduduk desa ini bermata pencaharian sebagai petani atau buruh tani karena lahan tanah disini subur sehingga cocok untuk melakukan kegiatan bertani. Kebanyakan petani yang berada di wilayah Desa Kedungbogo sendiri banyak yang lebih memilih untuk menanam padi dibanding tanaman yang lainnya. Akan tetapi dalam kegiatan bertani padi ini banyak yang mengalami kesuksesan dalam pertaniannya sehingga mereka lebih menggantungkan pendapatan mereka dari bertani.

Pendidikan di Desa Kedungbogo sendiri termasuk desa yang sudah memadai karena sudah tersedia PAUD, TK, RA, SD, MI, serta SMP yang mana memudahkan masyarakatnya untuk menyekolahkan anak mereka. Meskipun profesi dari masyarakat Desa Kedungbogo seorang petani ataupun buruh tani mereka masih memperdulikan kelanjutan sekolah untuk anak mereka.

Program lain dari divisi pendidikan yaitu "Kegiatan Ekstra Tari" dan "Pembelajaran Bahasa Arab dan Bahasa Inggris" dimana kegiatan ini ditujukan untuk siswa tingkatan SD dan MI yang ada di wilayah Desa Kedungbogo. Program "Kegiatan Ekstra Tari” ini dilakukan untuk mengenalkan dan mengajak para siswa untuk melestarikan tari tradisional yang ada di Indonesia. Tidak hanya sekedar mengenalkan dan mengajak akan tetapi mahasiswa KKNT UNHASY Kel. 28 juga mengajar dan memperaktekkan tari tradisonal yang kemudian di ikuti oleh para siswa yang mengikuti kegiatan ekstra tari ini. Sementara program tari berlangsung dengan siswa perempuan program "Pembelajaran Bahasa Arab dan Bahasa Inggris" pun juga berlangsung dengan siswa lakilaki. Dimana dengan adanya program pembelajaran Bahasa Arab dan Bahasa 
Inggris ini diharapkan siswa dapat mengenal bahasa asing. Karena di era ini para siswa dituntut dapat mengenal bahasa asing maka dengan pengadaan program ini dapat bermanfaat bagi siswa. Pelaksanaan kedua program ini pada hari Jum'at dan Sabtu di masingmasing sekolahan SD maupun MI.

Hasil analisis situasi yang ditemukan pada mitra adalah:

a. Kurang adanya pemahaman konsep dan pentingnya pendidikan seni budaya pada pembelajaran di kelas sehingga kurang dalam hal pengembangan karakter peserta didik menjadi manusia yang humanistis melalui olah cipta, rasa, dan karsa.

b. Tidak adanya guru dengan bidang spesialisasi seni budaya terutama tari, sehingga kurang dalam hal pengembangan kreativitas melalui seni budaya.

c. Pembelajaran seni di kelas tidak terlaksana dengan baik, mengakibatkan sikap apresiasi terhadap seni budaya tidak tampak pada diri siswa sehingga peran serta seni budaya pada tingkat lokal, regional dan global.

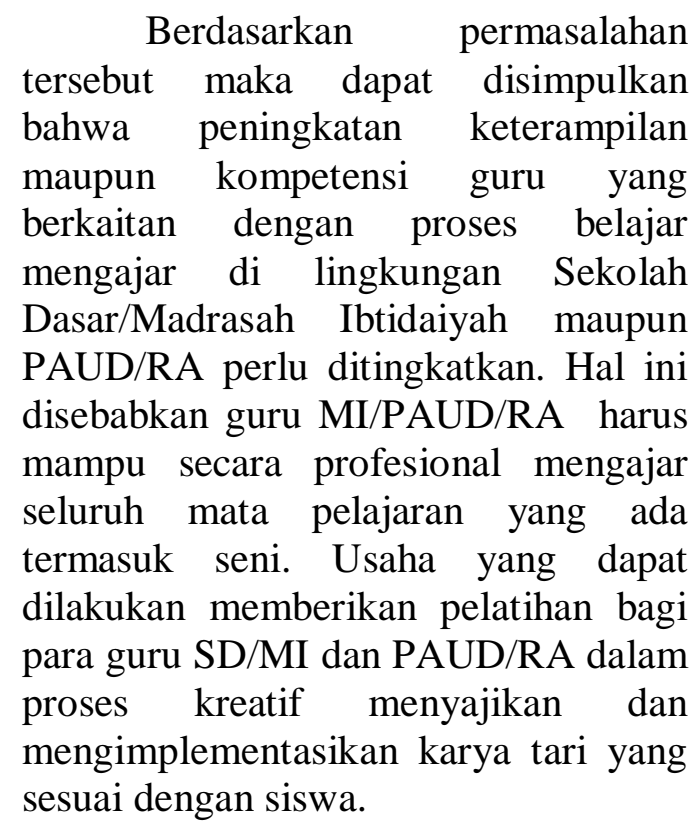

Berdasarkan permasalahan tersebut maka dapat disimpulkan bahwa peningkatan keterampilan maupun kompetensi guru yang berkaitan dengan proses belajar mengajar di lingkungan Sekolah Dasar/Madrasah Ibtidaiyah maupun PAUD/RA perlu ditingkatkan. Hal ini disebabkan guru MI/PAUD/RA harus mampu secara profesional mengajar seluruh mata pelajaran yang ada termasuk seni. Usaha yang dapat dilakukan memberikan pelatihan bagi para guru SD/MI dan PAUD/RA dalam proses kreatif menyajikan dan mengimplementasikan karya tari yang suai dengan siswa.
Dengan adanya pelatihan dalam PKM ini diharapkan tercapai tujuan jangka panjang yaitu: guru memahami konsep dan pentingnya pendidikan seni budaya sehingga mampu mengembangkan karakter peserta didik menjadi manusia yang humanistis melalui olah cipta, rasa, dan karsa, menampilkan sikap apresiasi terhadap seni budaya, menampilkan kreativitas melalui seni budaya, dan meningkatkan peran serta seni budaya pada tingkat lokal, regional dan global.

Menindaklanjuti dari salah satu program di bidang pendidikan KKNT mahasiswa UNHASY Jombang di Desa Kedungbogo Kecamatan Ngusikan Kabupaten Jombang, diantaranya melaksanakan Pelatihan Tari yang diajarkan kepada siswi-siswi MI. Adapun dalam pelaksanaannya terdapat kendala di lokasi tersebut, diantaranya; 1) belum adanya guru yang memiliki kemampuan di bidang tari, 2) belum adanya kegiatan ekstrakurikuler tari yang dilaksanakan di lembaga tersebut, akan tetapi 3) siswi-siswi yang telah dilatih mahasiswa KKNT di MI/PAUD/RA ini memiliki antusias yang tinggi terhadap pelatihan yang rutin diberikan. Sehingga diharapkan dengan adanya pelatihan ini, akan tercapai tujuan jangka panjang yaitu guru memiliki kompetensi professional dalam bidang tari, sekalipun MI Raden Fatah tidak memiliki guru tari, guruguru yang telah dilatih diharapkan tetap bisa mengajarkan tari kepada peserta didik.

\section{Metode}

Metode pelaksanaan PKM (pengabdian kepada masyarakat) adalah sebagai berikut: a) Analisis Situasi Mitra, b) Pengkajian pustaka yang terkait dengan tema PKM, c) Penyusunan materi yang akan 
disampaikan sebagai solusi masalah, d) Uji coba hasil pengembangan produk tari, e) Revisi produk tari (jika diperlukan), f) Pelaksanaan pelatihan di MI/PAUD/RA Raden Fatah Desa Kedungbogo Ngusikan Jombang, dan g) Pendampingan berkala.

\section{Hasil dan Pembahaasan}

Hasil penyuluhan dan pelatihan materi pembelajaran seni tari pada anak usia dini sebagai proses alih budaya terhadap guru-guru MI/PAUD/RA Raden Fatah Desa Kedungbogo Kecamatan Diwek Kabupaten Jombang secara garis besar dapat diuraikan sebagai berikut.

Solusi untuk mengatasi permasalahan yang dialami mitra adalah dengan memberikan pelatihan seni dalam bentuk kreasi baru sebagai upaya untuk meningkatkan kompetensi profesional Guru MI/PAUD/RA Raden Fatah Desa Kedungbogo Kecamatan Diwek Kabupaten Jombang. Salah satu solusi yang ditawarkan adalah memberikan wawasan pengetahuan tentang pentingnya pendidikan seni budaya khususnya seni tari dalam pembelajaran di sekolah. Hal ini disebabkan masih minimnya pengetahuan guru-guru MI/PAUD/RA RADEN FATAH tentang seni tari yang meliputi : (1) ruang lingkup seni tari dan unsur-unsurnya, (2) pemilihan jenis tari yang sesuai dengan tingkat usia anak, (3) elemen-elemen penciptaan tari, (4) tata teknik pentas, (5) tata rias dan busana, (6) musik pengiring tari, (7) teknik pengelolaan pertunjukan tari, (8) proses pengalihan nilai-nilai budaya melalui media gerak tari, (9) teknik memeragakan gerak tari.

1) Ruang Lingkup Seni Tari dan Unsur-unsurnya
Penyuluhan materi seni tari dan unsur-unsurnya yang diberikan kepada guru-guru MI/PAUD/RA RADEN FATAH meliputi pengertian tari dari berbagai pendapat diantaranya John Martin, Soedarsono, Sussane K. Langer, Corrie Hartong, Doris Humprey dan Pangeran Suryodiningrat. Karena pada dasarnya tari adalah gerak, maka dijelaskan pula elemen-elemen dasar gerak yang meliputi ruang, waktu, dan tenaga. Aspek ruang terdiri dari posisi, level, volume dan fokus. Waktu meliputi ritme gerak atau irama gerak dan tempo gerak. Sedangkan tenaga dalam tari adalah kekuatan yang mengawali, mengendalikan dan menghentikan gerak mulai dari halus, ringan, sedang, kuat dan keras.

Disamping elemen-elemen dasar gerak, dijelaskan juga nilai-nilai keindahan yang terkandung dalam tari yang meliputi wiraga, wirama dan wirasa. Wiraga meliputi hafalan, teknik dan ruang gerak. Keindahan pada aspek wirasa menyangkut penjiwaan atau kemampuan penari di dalam mengungkapkan rasa emosi yang sesuai dengan karakter dan tema tarian. Sedangkan wirama meliputi ketepatan ritme dan tempo gerak yang selaras dengan irama iringannya.

Hasil yang didapat dalam penyuluhan materi tersebut adalah tingkat pengetahuan dan pemahaman guru-guru MI/PAUD/RA RADEN FATAH Kabupaten Jombang dari awalnya $53 \%$ menjadi $78 \%$. Hal ini menunjukkan tingkat keberhasilan dalam penyerapan materi meningkat secara signifikan.

2) Pemilihan Jenis Tari yang Sesuai dengan Tingkat Usia Anak

Tujuan pendidikan seni (seni tari) adalah membentuk manusia seutuhnya yang mampu mengembangkan 
kepekaan estetisnya, daya cipta, intuitif, imajinatif, motivatif dan kritis terhadap lingkungannya. Pembelajaran seni tari di tingkat sekolah formal termasuk diantaranya pendidikan pra sekolah tidak semata-mata membentuk siswa menjadi seniman profesional, akan tetapi lebih pada proses aktualisasi diri dan kreatifitas siswa melalui media gerak. Oleh karena itu, diberikan pula penyuluhan tentang pemahaman mengenai berbagai jenis tari, dan karakteristik anak usia dini, sehingga diharapkan guru-guru MI/PAUD/RA RADEN FATAH Kabupaten Jombang mampu memilihkan jenis tari yang sesuai dengan tingkat perkembangan anak.

Hasilnya, guru-guru mampu menentukan jenis tari yang seharusnya dan tidak seharusnya diberikan kepada siswa berdasarkan tingkat perkembangan anak yang diprosentasekan sejumlah 69\%. Hal ini menunjukkan tingkat keberhasilan dalam penyerapan materi meningkat cukup signifikan.

3) Elemen-elemen Penciptaan Tari

Jenis-jenis tari yang sesuai dengan karakter anak usia dini, tidak sebanyak materi tari untuk usia dewasa. Untuk memenuhi kebutuhan siswa akan materi seni tari tersebut, maka guruguru MI/PAUD/RA RADEN FATAH dituntut untuk dapat menciptakan tari yang sesuai dengan karakter dan tingkat usia anak Taman Kanak-kanak. Oleh karena itu diberikan pula penyuluhan pengetahuan dan pelatihan tentang proses penciptaan tari untuk anak usia dini secara sederhana. Elemen-elemen penciptaan tari meliputi gerak, pola lantai, level, komposisi gerak, iringan, tata rias dan busana. Dalam proses pelatihan penciptaan tari, guru-guru diajak untuk melakukan observasi gerak, improvisasi gerak kemudian mempraktekkan gerak-gerak tari yang diciptakannya.

Hasil dari observasi dan improvisasi gerak, disusun menjadi rangkaian gerak yang mempunyai makna dan nilai keindahan. Setelah menciptakan gerak-gerak tari, maka dilakukan praktek pembuatan pola lantai, menentukan level, komposisi gerak, membuat iringan tari secara sederhana. Hasil yang didapat dalam penyuluhan dan pelatihan materi tersebut adalah meningkatnya pengetahuan, pemahaman dan keterampilan guru-guru MI/PAUD/RA RADEN FATAH Kabupaten Jombang dalam proses penciptaan tari untuk anak usia dini meskipun masih secara sederhana sejumlah $72 \%$.

4) Tata Teknik Pentas

Dalam seni tari, pentas merupakan bagian yang tidak dapat ditinggalkan. Pentas adalah tempat yang digunakan oleh seorang penari dalam menampilkan kemampuannya menari dihadapan penonton. Karena pentas sangat erat kaitannya dengan tari, maka seluk beluk tentang pentas juga diberikan dalam penyuluhandan pelatihan tersebut, diantaranya adalah mengenal bermacam-macam bentuk pentas, perlengkapan pentas, penataan dekorasi pentas, tata lampu, dan tata bunyi pentas bagi anak usia dini.

$\begin{array}{cr}\text { Hasilnya } & \text { guru-guru } \\ \text { MI/PAUD/RA RADEN } & \text { FATAH }\end{array}$ Kabupaten Jombang lebih memahami dan mempunyai keterampilan mengenai seluk beluk pentas yang akan digunakan sebagai bekal dalam mempersiapkan pementasan akhir tahunan anak didiknya.

5) Tata Rias dan Busana

Tata rias dan busana merupakan bagian dari tari yang tidak dapat ditinggalkan. Pada umumnya seseorang 
46 | EmyYunita Rahma Pratiwi, dkk : Pelatihan tari kreasi...

yang mempunyai kemampuan menari, belum tentu mempunyai kemampuan menata rias dan busana sendiri, sehingga mereka masih memerlukan bantuan orang lain untuk menata rias dan busananya. Oleh karena itu, guruguru MI/PAUD/RA RADEN FATAH Kabupaten Jombang diberikan juga teknik menata rias dan busana untuk anak usia dini. Hal ini penting, karena apabila siswanya menari, guru-guru tidak perlu lagi mengambil perias dari luar sekolah, tetapi bisa dilakukan sendiri, dengan demikian akan lebih menghemat pengeluaran. Materi rias dan busana yang diberikan adalah rias cantik, rias karakter, rias lucu lengkap dengan busananya sesuai dengan tingkat usia anak.

Hasilnya, guru-guru mampu memahami dan mempraktekkan pengetahuan dan keterampilan tentang rias dan busana tari untuk anak usia dini.

6) Musik Pengiring Tari

Tari tidak dapat dinikmati dengan enak tanpa musik pengiringnya. Di dalam proses penciptaan tari tidak terlepas dari musik pengiring. Oleh karena itu, guru-guru juga diberikan penyuluhan dan pelatihan tentang musik pengiring tari secara sederhana, baik pengenalan tentang notasi balok, teknik memainkan alat musik misalnya pianika, angklung, drum, okolele dan teknik menyanyi. Lagulagu yang diajarkan adalah Balonku Ada Lima, Bintang Kejora, Hujan, Pamanku Datang, menthok-menthok dan lain-lain.

Lagu-lagu ini bisa diisi dengan gerak tari. Hasil dari penyuluhan dan pelatihan ini, guru- guru MI/PAUD/RA RADEN FATAH Kabupaten Jombang mampu memahami dan mempraktekkan alat-alat musik dan lagu-lagu yang diberikan.

7) Teknik Pengelolaan Pertunjukan Tari

Setelah

MI/PAUD/RA RADEN FATAH

Kabupaten Jombang memahami dan mempunyai keterampilan menciptakan tari secara sederhana untuk anak usia dini, maka perlu adanya pengetahuan dan keterampilan dalam pengelolaan sebuah pertunjukan. Pertunjukan seni ini biasanya diadakan oleh pihak sekolah pada setiap akhir tahun untuk acara kenaikan kelas atau kelulusan, atau pada hari-hari besar lainnya.

Acara pentas akhir tahun atau peringatan hari-hari besar nasional, dikemas oleh guru-guru yang bersangkutan. Materi pengeloalan pertunjukan tari ini meliputi: perencanaan (penentuan tanggal pelaksanaan, tempat, tema acara, materi acara, undangan, leaflet, susunan acara), persiapan (tentang segala sesuatu yang dibutuhkan dalam acara tersebut, mempersiapkan pentas, susunan acara, dan pengisi acara), pelaksanaan (mengatur jalannya acara supaya lancar). Secara teoretis, guruguru MI/PAUD/RA RADEN FATAH memahami semua materi penyuluhan yang diberikan dengan baik.

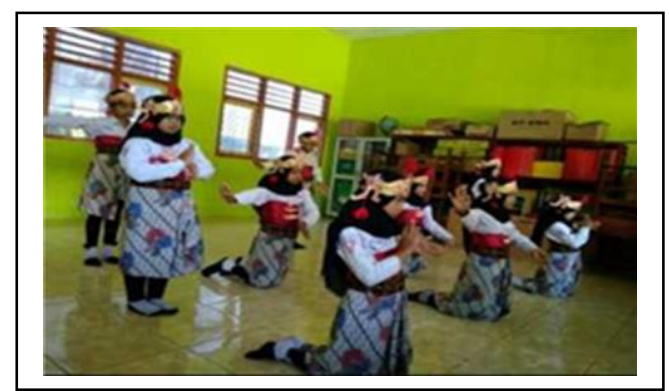

Gambar 1. Tari Kreasi 
47 |EmyYunita Rahma Pratiwi, dkk : Pelatihan tari kreasi...

8) Proses Pengalihan Nilai-nilai Budaya Melalui Media Gerak

Pengetahuan dan pelatihan mengenai proses pengalihan nilai-nilai budaya melalui media gerak diberikan, agar guru-guru dalam melakukan proses pembelajaran seni tari secara tidak langsung dapat mengajari anak usia dini mampu melakukan proses sosialisasi, internalisasi, enkulturasi budaya. Proses sosialisasi dapat dilakukan melalui menari dengan berkelompok, berpasangan untuk saling berinteraksi dengan sesama teman atau dengan penonton disekitarnya.

Proses internalisasi dalam menari, yaitu mengajarkan siswa untuk belajar mencintai budayanya sendiri dengan cara menarikan tarian yang berasal dari daerahnya sendiri. Proses enkulturasi adalah proses pengenalan budaya daerah lain atau negara lain kepada anak melalui menari.

Hasil dari penyuluhan materi tersebut, guru-guru MI/PAUD/RA RADEN FATAH Kabupaten Jombang mempunyai tambahan pengetahuan dan keterampilan untuk mengajarkan anak usia dini melakukan proses sosialisasi, internalisasi, dan enkulturasi budaya melalui media gerak tari.

9) Teknik Memeragakan Gerak Tari

Teknik memeragakan gerak tari yang baik juga diberikan dalam pelatihan pembelajaran seni tari pada anak usia dini, dengan tujuan meningkatkan kemampuan guru- guru MI/PAUD/RA RADEN FATAH Kabupaten Jombang dalam pembelajaran seni tari. Hasilnya, pengetahuan dan kemampuan menari guru-guru MI/PAUD/RA RADEN FATAH Kabupaten Jombang mengalami peningkatan.

Hasil analisis yang ditemukan adalah: a) Kurang adanya pemahaman konsep dan pentingnya pendidikan seni budaya pada pembelajaran di kelas sehingga kurang dalam hal pengembangan karakter peserta didik menjadi manusia yang humanistis melalui olah cipta, rasa, dan karsa. b) Tidak adanya guru dengan bidang spesialisasi seni budaya terutama tari, sehingga kurang dalam hal pengembangan kreativitas melalui seni budaya. c) Pembelajaran seni di kelas tidak terlaksana dengan baik, mengakibatkan sikap apresiasi terhadap seni budaya tidak tampak pada diri siswa sehingga peran serta seni budaya pada tingkat lokal, regional dan global.

Berdasarkan permasalahan tersebut maka dapat disimpulkan bahwa perlu adanya a) peningkatan keterampilan maupun kompetensi guru yang berkaitan dengan proses belajar mengajar di lingkungan Sekolah Dasar/Madrasah Ibtidaiyah maupun PAUD/RA perlu ditingkatkan.

b) adanya pelatihan dalam PKM ini diharapkan menjadikan guru memahami konsep dan pentingnya pendidikan seni budaya c) mengembangkan karakter peserta didik menjadi manusia yang humanistis melalui olah cipta, rasa, dan karsa, menampilkan sikap apresiasi terhadap seni budaya, menampilkan kreativitas melalui seni budaya, dan meningkatkan peran serta seni budaya pada tingkat lokal, regional dan global.

\section{Simpulan}

Berdasarkan dengan hasil dari pengabdian kepada masyarakat oleh tim di MI/PAUD/RA RADEN FATAH Kabupaten Jombang tentang pelatihan pembelajaran seni tari sebagai proses alih budaya pada anak usia dini bagi guru-guru MI/PAUD/RA RADEN FATAH Kabupaten Jombang, dapat disimpulkan sebagai berikut :

a. Pengetahuan dan keterampilan pembelajaran seni tari yang dimiliki oleh guru MI/PAUD/RA RADEN 
48 | EmyYunita Rahma Pratiwi, dkk : Pelatihan tari kreasi...

FATAH Kabupaten Jombang yang pada awalnya masih terbatas, setelah mendapat penyuluhan dan pelatihan pembelajaran seni tari oleh tim pengabdian kepada masyarakat menjadi meningkat dari awalnya $53 \%$ menjadi $78 \%$. Hal ini menunjukkan tingkat keberhasilan dalam penyerapan materi meningkat secara signifikan.

b. Materi pembelajaran seni tari pada anak usia dini di MI/PAUD/RA RADEN FATAH Kabupaten Jombang yang pada awalnya diadopsi dari pencipta tari, setelah mendapatkan penyuluhan dan pelatihan dari Tim pengabdian kepada masyarakat, merupakan hasil cipta guru-guru MI/PAUD/RA RADEN FATAH itu sendiri. Hasilnya, guru-guru mampu menentukan jenis tari yang seharusnya dan tidak seharusnya diberikan kepada siswa berdasarkan tingkat perkembangan anak yang diprosentasekan sejumlah $69 \%$. Hal ini menunjukkan tingkat keberhasilan dalam penyerapan materi meningkat cukup signifikan.

c. Kemampuan tata rias dan busana, tata teknik pentas, yang semula ditangani oleh perias dan penata busana dan penata pentas dari luar sekolah, setelah ada penyuluhan dan pelatihan dari tim pengabdian kepada masyarakat, dapat ditangani sendiri oleh guru MI/PAUD/RA RADEN FATAH.

d. Kemampuan pengelolaan pertunjukan seni tari juga dimiliki oleh guru MI/PAUD/RA RADEN FATAH setelah mendapatkan penyuluhan dan pelatihan oleh tim pengabdian kepada masyarakat. e. Pembelajaran seni bagi anak usia dini yang pada mulanya dilakukan oleh guru seni tari dari luar yayasan, setelah mendapatkan penyuluhan dan pelatihan oleh tim pengabdian kepada masyarakat dapat dilakukan oleh guru tetap MI/PAUD/RA RADEN FATAH itu sendiri.

\section{Daftar Pustaka}

Asmarani, Ratih. (2020). Pelatihan Tari Kreasi Baru sebagai Upaya Peningkatan Kompetensi Profesional Guru MI/PAUD/RA RADEN FATAH Raden Fatah di Desa Kedungbogo Kecamatan Ngusikan Jombang. (Laporan Pengabdian Kepada Masyarakat tidak dipublikasikan). LPPM UNHASY, Jombang.

Humprey, Dories. (1983). Seni Menata Tari Terj. Sal Murgianto. Jakarta: Dewan Kesenian Jakarta.

Kusumastuti, Eny. (2003). Pendidikan Seni Tari Pada Anak Usia Dini di MI/PAUD/RA RADEN FATAH Cabang Erlangga Jombang Sebagai proses Alih Budaya. (Laporan Penelitian tidak dipublikasikan). Lembaga Penelitian, Universitas Negeri Semarang.

Langer, Sussane K. (1988). Problematika Seni Terj. FX. Widaryanto. Bandung: ASTI Bandung.

Narawati, Tati \& Masunah Juju. (2003). Seni dan Pendidikan Seni. Bandung: P4ST UPI.

Salmurgiyanto. (2002). Kritik Tari Bekal dan Kemampuan Dasar. Jakarta: Fond Foundation \& Masyarakat Seni Pertunjukan Indonesia. 
49 | EmyYunita Rahma Pratiwi, dkk : Pelatihan tari kreasi...

Sedyawati, Edi. (1984). Tari. Jakarta: Perpustakaan Jaya.

Soedarsono. (1978). Pengantar Pengetahuan Tari. Yogyakarta: ASTI.

Sumaryono. (2008). Jejak dan problematika Seni Pertunjukan Kita. Yogyakarta: Prasista 